\title{
THE ROLE OF TEACHERS ON STUDENTS' PEER GROUPS RELATIONS: A REVIEW ON THEIR INFLUENCE ON SCHOOL ENGAGEMENT AND ACADEMIC ACHIEVEMENT*
}

\author{
EL ROL DE LOS PROFESORES EN LAS RELACIONES DE LOS GRUPOS DE \\ PARES DE LOS ESTUDIANTES: UNA REVISIÓN SOBRE SU INFLUENCIA EN EL \\ COMPROMISO ESCOLAR Y EL RENDIMIENTO ACADÉMICO
}

\author{
Javiera Muñoz-Hurtado** \\ Universidad de Tarapacá (UTA), \\ Arica - Chile.
}

Recibido marzo de 2018/Received March, 2018

Aceptado agosto de 2018/Accepted August, 2018

\begin{abstract}
RESUMEN
El propósito de este ensayo es analizar por qué y cómo los profesores deberían preocuparse sobre las interacciones entre pares en el contexto escolar. Es ampliamente reconocido que las relaciones de grupo de pares son fundamentales para el desarrollo infantil, afectando tanto la participación escolar como los logros académicos. Sin embargo, existe poco análisis sobre cuál sería el rol de los profesores sobre estas relaciones entre iguales. Para lograr el objetivo del ensayo se realiza un análisis de la literatura sobre los dos siguientes temas: 1) las relaciones entre pares en el contexto escolar, considerando los conceptos de homogeneidad y compromiso, teniendo en cuenta las tres dimensiones informales de las relaciones entre pares: amistad, estatus y centralidad; 2) influencia de los docentes sobre la relación entre pares, considerando sus roles como protectores, "arquitectos" o referentes sociales, así como considerando su participación en dos enfoques pedagógicos diferentes: el modo de performance o el modo cooperativo de enseñanza. Se concluye que los profesores deben preocuparse por las relaciones informales de los estudiantes, ya que conscientemente o no, influyen en ellas. Si los maestros toman un rol activo en promover relaciones positivas y saludables en la escuela, estarían promoviendo el desarrollo infantil y fomentando un mejor rendimiento escolar. Teniendo en cuenta la literatura, se sugiere que los profesores adopten un modo cooperativo de enseñanza, actúen como referentes para el comportamiento de sus alumnos y eviten la retroalimentación negativa a los niños rechazados por su agresividad, con tal de evitar un mayor rechazo por parte de sus compañeros.
\end{abstract}

Palabras Clave: Grupos de pares, relación profesor-estudiante, compromiso académico, relaciones de pares, desarrollo infantil.

\begin{abstract}
The purpose of this essay is to analyse why and how teachers should concern themselves with informal peer interactions in the school. It is widely acknowledged that peer group relations are fundamental for children's development, affecting both, school engagement and students' academic achievement. However, it has been less discussed what is the role of teachers on these relations. To accomplish the goal of the essay ananalysis of the literature on the two following topics is conducted: 1) peer relationships in the school context, considering the concepts of homogeneity and engagement, and taking into account the three informal dimensions of peer relations: friendship, status and centrality; 2) teachers' influence on peer relation, considering their
\end{abstract}

* Funding: This work was supported by CONICYT (Becas Chile) and Cambridge Trust (Santander Cambridge Scholarship). Se agradece el apoyo recibido en el marco del CM UTA1756 "Vinculación, Fortalecimiento Académico e Investigación: Un enfoque en red nacional en la FID - UTA".

** Autor correspondiente / Correspondig author: jmunozh@uta.cl 
roles as protectors, 'architects' or social referents, as well as considering their participation in two different pedagogical approaches: the performance mode or the cooperative mode of teaching. It is concluded that teachers should concern themselves with children's informal relationships at school, as they consciously or not, influence those relationships. If teachers take an active role in promoting positive and healthy relationships at school, they will be promoting children's development and fostering school performance. Considering the literature, it is suggested that teachers should adopt a cooperative mode of teaching, act as social referents for their students' behaviour and avoid negative feedback to aggressive-rejected children to prevent further rejection.

Key Words: Peer groups, teacher-student relationship, academic engagement, peer relations, children development.

\section{Introduction}

Children at school develop informal relationships with their peers. These relations are important for children's development, in terms of personal, social and emotional aspects of development (Newcomb \& Bagwell, 1996; Wentzel, 2009). There is also evidence that informal peer interactions and the general social climate of the classroom affect both school engagement and students' academic achievement (Kindermann, 2007; Skinner \& Bemont, 1993). Furthermore, based on the works of Piaget and Vygotsky, educational psychologists consider that children's interactions are pivotal for cognitive development. In this essay we will look at why and how teachers should concern themselves with these relations It starts by explaining the peer group context at school, referring to two important concepts: homogeneity and engagement. In the second part, research on peer relationships and school performance is reviewed by means of trough three constructs developed in the peer group field: friendship, sociometric status and centrality. Then studies on teachers' role and influence are analysed. Finally, it concludes by discussing how teachers and the educational system should concern itself with informal peer relationships. Notably, this essay does not intend to analyse the problem from a human development perspective. The phenomenon is approached in different educational cycles, understanding that early experiences affect children and adolescent development in later evolutionary stages. However, the subject is not discussed, since it goes beyond the scope of the study.

\section{Peer groups in the school context}

As reviewed by Christine Howe in her book 'Peer groups and children's development' (2010), peer groups consist of two or more people of similar age and rank. She depicts schools as formal peer group institutions, products of cultural evolution, in which children develop informal relationships.
Research on peer groups has traditionally considered three different constructs: friendship, sociometric status and centrality. While 'friendship' refers to the reciprocal dyadic relationship, 'sociometric status' is related to the degree to which a child is accepted or rejected by their peers, and 'centrality' refers to the position of the child in the informal peer network. Even though these three dimensions of children's informal relations tend to be studied separately, they are interconnected, complementary, and are all required for an understanding of peer relationships. The way in which children build and experience these relationships depends not only on contextual aspects, but also on children's individual characteristics. Three characteristics are recognised as playing important roles in peer relations, namely, sociability, aggressiveness and social withdrawal (Howe, 2010; Newcomb, Bukowski, \& Pattee, 1993; Parker \& Asher, 1987). Depending on children's level of sociability, aggression and withdrawal, the shape of their relationships will vary. But far from being static - or inborn - features, these individual characteristics are built and interact within the social context in which they are shaped. For example, the levels of children's aggression can vary depending on the social context response. In this sense, Chang (2003) found that teachers who show more aversion to aggression promote rejection of the aggressive student, which in turn could result in higher levels of aggression from that child.

Within the literature on peer relationships, discussed below, there is abundant information about the negative consequences of problematic peer relations. There is less work, though, on the positive learning potential that the existence of peer group has for children's cognitive development. Classical works on friendship dyads have paid attention to the cognitive enhancement that children interaction can stimulate (see Newcomb and Bagwell (1995) for a meta-analytic review), but generally the works on sociometric status and centrality have focused 
on peer group conflict and negative relationships (i.e.; De Laet, Doumen, Vervoort, Colpin, Leeiven, Goossens, \& Verschueren, 2014). Accordingly, there has been interest in how the educational milieu can help to develop interventions focused on classroom management, positioning teachers as promoters of healthy classroom climates and controllers of social dynamics, ensuring the scope of their concerns includes those roles.

A different perspective comes from works on cooperative learning, in which peer interactions are valued as fundamental to children's cognitive development, drawing on the classical works of Piaget and Vygotsky. For Piaget (1932, in Howe, 2010), interactions with peers are determinants for cognitive growth, since they provide symmetrical conditions for an enriched opposition of views, which will provoke the cognitive conflict that is needed for cognitive development. For Vygotsky $(1978 ; 1981)$, the interaction with others (peers, adults and culture) provides the basis for cognitive growth as he considers that the mind is developed through social interaction in a dialectic process between the social and psychological planes, starting with the internalisation of interpsychological categories on the social plane. In this perspective, Howe (2010) contributes to the literature on peer groups proposing that peer interactions in the classroom have to be understood in their pedagogical context or 'mode'. She contrasts the traditional performance mode with a different approach, which she calls cooperative mode, in which peer relations and teacher-student relationships are experienced in a different way.

As noted, students' informal relationships have a generally recognised importance in educational research and school interventions. The influence teachers, in turn, have on those relationships has been less explored, but a body of research on the topic has been growing during years (Farmer, McAuliffe, \& Hamm, 2011). These studies are mostly based on Bronfenbrenner's ecological perspective, which considers classroom relationships in terms of reciprocal influences and the proximity of everyday social interactions as the 'engines of development' (Kindermann, 2011). From this approach teachers are seen as both 'architects' of classroom interactions and social referents for the children's perception of their classmates.

\section{Peer relationships, homogeneity and engagement}

Studies on the three dimensions of peer relationships, namely, friendship, status and centrality, have evidenced that when children develop relationships at school they associate with children with similar characteristics. Typical features in which peer groups show similarities are gender, social background, psychosocial characteristics, and levels of school engagement, achievement and motivation (Howe, 2010; Kindermann, 2007; Wentzel, 2009; Zajac \& Hartup, 1997). By the effect of later socialization homogeneity may potentially increase in time (Newcomb \& Bagdwell, 1996), which could have detrimental implications for school performance if the relationships are characterised by negatives characteristics, like aggressive behaviour or low achievement. It is important to acknowledge that certain school practices in which teachers' direct influence can be identified, like ability grouping, reinforce student homogenisation and polarisation (Boaler, Wiliam, $\&$ Brown, 2000; Howe, 2010).

The concept of engagement is also significant within the literature on peer group relations in particular, and that on school interactions in general. School engagement will be understood as the emotional, behavioural and cognitive involvement of students in their academic activities, which can vary depending on contextual factors (Fredricks, Blumenfeld, \& Paris, 2004). In relation to school environment, studies have found that children who develop positive relationships with their peers and teachers are generally more engaged and motivated in school, increasing the possibilities for better academic performance (Wentzel, 2009). In contrast, negative experiences with the peer group and conflictual relationships with teachers are typically associated with school disengagement (Buhs, Ladd, \& Herlad, 2006; Skinner \& Belmont, 1993).

The level of engagement of the group and the 'group norm' to which children belong has been shown to influence students' individual behaviour and school performance. A study made by Kindermann (2007) during one academic year with an entire cohort of 366 sixth graders (11-13 years old) in their natural school environment evidenced that peer groups were homogeneous in terms of levels of engagement, which had an effect in the levels of engagement throughout the year. 
Whereas members from highly engaged groups at the beginning of the year tended to maintain or increase their levels of engagement by the end of the year, students from less engaged networks tended to decrease their engagement. Even though this influence was shown to be rather small, it appeared as an existing predictor of behavioural and emotional engagement. In this example not only does the 'sense of belonging', that is, the feeling of being related to a group (Furrer \& Skinner, 2003), play a role in academic outcomes, but also play a role the 'behavioural norm' of the group, to which students respond. In support of that, Chen, Chang and He (2003), in a study with a large sample of Chinese children and teenagers, found that both students' academic performance and social adjustment were related to the group norm to which children aligned themselves. In short, from the findings of both studies it is possible to maintain that children are influenced by their group, to which they respond with an active adjustment of their individual behaviour in order to increase their sense of belonging to that group.

\section{Friendship, Status and Centrality}

The research on peer groups is analysed in this section, taking into account its three informal dimensions: friendship, status and centrality. For practical purposes, these studies are analysed separately, but also because the research traditions with regard to on the topics have followed different paths as noted by Howe (2010).

\section{Friendship}

Studies on friendship have traditionally focused on the close relationship between two children (dyadic), which is characterised by intimacy, equality, reciprocity, cooperation and commitment (Newcomb \& Bagwell, 1996). There are several studies that compare how working with a friend differs from working with a non-friend in terms of cognitive enhancement. Newcomb and Bagwell (1995) in a meta-analytic review found that when friends work together, there is greater engagement, more frequent conflict resolution and more collaborative and effective task performance. In another review, Zajac and Hartup (1997) summarised that friends perform equally or better than non-friends in a range of different tasks: seeking scarce resources, problem solving, written narratives, and normative/social issues. They conclude that friends are better co-learners, because interactions amongst friends are more accurate and are developed in a more affective climate, in which children feel less defensive about contradictions and criticism, which provides a better learning context. Additionally, Hartup (1996) concluded that the contribution of relationships with friends to cognitive development is related to the regulative functions of planning, monitoring and evaluating outcomes that are especially present in interactions with friends.

Even when some interesting findings have emerged from these studies, especially as friends dyadic appear as productive interactions that can promote learning in line with Piaget's and Vygotsky's approaches, it seems they do not provide the whole picture of peer informal relations at school. One reason is that they have normally been studied in experimental situations, ignoring the whole social context of the classroom, and also ignoring the fact that some children do not even experience close and reciprocal relationships. More relevant is the notion that the existence of a mutual friendship relationship can provide a supportive context for children development (Newcomb \& Bagwell, 1996). In this sense, the existence of a mutual friend for a child can contribute to school adjustment (Ladd, Kochenderfer, \& Coleman, 1997), and it can become a protective factor against peer conflict, victimisation, and even family risk factors (Bukowski, Motzoi, \& Meyer, 2009).But, as shown by Cuadros and Berger (2016) with 614 Chilean adolescents, the quality of friendships relations also affect peer victimisation and students wellbeing, specifically the dimensions of disclosure and support in the relation. Furthermore, as Hartup (1996) suggests it, what matters is not just the existence of a mutual friendship relationship or its quality, but also the identity of a child's friend, for example, the high-quality relationship of aggressive friends could mean negative consequences for the individual, and also for the classroom dynamics. Along the same lines, Howe (2010) suggests that children without friends, as well as children who are rejected by their classmates, or children that develop friendships with academically low-achieving friends are at higher risk of having problematic experiences at school and are even at greater risk of school failure.

As the understanding of friendship and peer relationships is deepened, and the focus moves from the positive dyadic relationships to a more intricate and extended group organisation, the 
romantic characteristics of equality, reciprocity, cooperation and commitment of friendship seem to run in parallel with more complex peer group characteristics and relationships, as do, for example, rejection, isolation, domination and group influence (Cairns, Xie, \& Leung, 1998). These dimensions are now reviewed under the constructs of status and centrality.

\section{Sociometric status}

Sociometric status refers to the degree to which a child is liked or disliked by their peers. Its assessment is associated with Moreno's sociometry, which was first developed in 1934, whereby children report who they are attracted to and who they reject, basically by nominating classmates they like and classmates they do not like (Hartup, 2009). The peer evaluation scores are summarised into five categories: popular, rejected, neglected, controversial and average (Coie, Dodge, $\&$ Coppotelli, 1982). Even though this strategy for measuring peer relations is widely used in research, an ethical issue arises in terms of how sensitive it is to ask children directly about rejection, especially in classrooms with high levels of victimisation.

In relation to the three individual characteristics that are associated with peer relations, namely sociability, aggression, and withdrawal, Newcomb, et al. (1993), in a meta-analytic review, revealed that popular children were sociable and highly accepted by their classmates, rejected children showed high levels of aggression and withdrawal, neglected children showed low sociability and low aggression, and controversial children were highly aggressive but at the same time possessed social abilities, resulted in them being both liked and disliked by their classmates.

Research on academic achievement indicates that socially accepted children perform better academically, whereas children who experience negative peer relationships have more academic difficulties (Wentzel, 2009). Low acceptance by peers is related to higher levels of drop-out (Parker $\&$ Asher, 1987). In the same vein, controversial and rejected children tend to have more behavioural and attention problems, and higher probability of failing at school and dropping out (Ollendick, Weist, Borden, \& Greene, 1992). Peer rejection has been shown to be a school stressor, which from early kindergarten onwards affects school adjustment, being related to school avoidance, lower academic performance and negative attitude towards school
(Ladd, 1990). In support of this, DeRosier and Lloyd (2010) in a one-year study with 1,255 third-grade students found that absenteeism from school was related to rejection through aggression.

The previous findings are disturbing considering the general continuity of the sociometric status categories that Coie and Dodge (1983) encountered in their five-year longitudinal study. They observed that the rejected category was the most stable of all, and that aggressive rejected children showed even higher levels of aggression, which could be interpreted as a vicious circle of reinforcement. A different finding regarding academic achievement was produced by Buhs et al. (2006) in a study with 380 children (5-11 years) in which aggressive-abused children tended to avoid school, but, contrary to what was expected, this fact did not affect their academic achievement. This contradiction may be explained by considering other sources of school motivation, like parental influence, or it could also be related to the child's personality and interests. In the same study, the authors found that the greatest academic implications of rejection were associated with the child's social withdrawal which derived from peer exclusion, but not from aggression. In these cases children disengaged from school activities, reducing their classroom participation, which in turn was negatively correlated with school achievement. In a previous more detailed investigation, Ladd and Burgess (1999), studying 492 children from kindergarten to second grade, found that the most problematic prediction was for children who showed comorbidity of both aggression and withdrawal; those children presented more difficulties with their peers, were at higher risk of being victimised, and also experienced more conflict with their teachers.

Howe (2010) notes that compelling evidence exists to relate peer rejection to problems in both social and personal development. She explains that if rejection is based on child aggression, problems of social adjustment, like conduct disorders or criminality, are more likely to occur. Rejection grounded on withdrawal is related to difficulties in personal development, like high levels of anxiety, depression and low self-esteem. In sum, Howe proposes that rejection grounded on aggression is associated with externalising problems, while rejection based on withdrawal is associated with internalising problems. 
The evidence of peer rejection in studies on sociometric status contributes enormously to an understanding of the relevance of children's informal relationships in the classroom and to highlighting the worrying negative consequences of aggression, peer rejection and victimisation for children's development and school performance. Newer studies on centrality contribute to a comprehension of the complex phenomenon of peer relationships, recognising that peer interactions go beyond peers liking or disliking, also existing power relationships where leaders emerge as important figures of the classroom.

\section{Centrality in the peer network}

Peer networks or cliques are defined as "cohesive groups of youth who spend time together" (Bagwell, Coie, Terry, \& Lochman, 2000, p.281). As Cairns et al. (1998) reflect in the wording of their article's title: The popularity of friendship and the neglect of social networks: toward a new balance, the informal dimension of children's networks has been less explored and is a newer area of research. Even though centrality in the network is related to the other two constructs, it brings to light other characteristics of peer relationships, depending on the position members occupy in their clique, like domination, admiration and contempt (Howe, 2010).

To assess centrality, children are asked 'who hang around together a lot?' With that information it is possible to construct a socio-cognitive map, as developed by Robert Cairns, in which the different cliques can be recognised and the position of each member inside them subsequently determined (Kindermann \& Gest, 2009). As the question does not address the matter of liking or disliking, the response of the children is related to who they perceive as popular and depending on how many times a child is nominated, the centrality of that member is determined (Cairns, Cairns, Neckerman, Gest, \& Gariepy, 1988). There are clear differences between the sociometric popularity and the central members - or perceived popularity. While children who are sociometrically popular are characterised by prosocial behaviour, perceived popularity has been also related to aggression and domination (De Laet, et al., 2014; Parkhurst \& Hopmeyer, 1998).

One of the most interesting studies on the complexity of clique dynamics was conducted by Adler and Adler (1995). This married couple led a seven-year ethnographic study in which, using their parental position, immersed themselves in the children's social dynamics at a school in the USA, doing participant observation and conducting interviews with students, parents and teachers, both inside and outside the school. The fact that they could access to out-off-school settings is relevant because studies on peer groups have been traditionally carried out only within school settings. In this study, the authors highlight the fact that cliques are hierarchical structures, markedly stratified around a central member. The central members of the group are recognised as 'leaders', who are followed by other members described as 'followers'. Other children who have contact with the group but are not considered part of the group by their members are defined as 'wannabes', and peers who are not part of any group are identified as 'isolated'. The cliques develop dynamics of exclusion and inclusion to maintain the functioning and boundaries of the group. The rules of those dynamics are generally linked to the power of the leader, who exerts his/ her power in establishing the norms of the group, thus contributing to forming the group's identity and characteristics. These dynamics establish the norms for the exclusivity of the group, the relations that are allowed inside and outside the clique, the hierarchy, and the dominance-submission patterns that characterise the particular clique (Adler \& Adler, 1995; Howe, 2010).

Although different roles and positions exist inside cliques, there is a tendency for children and adolescents to engage with people with similar characteristics. Members of a clique are normally similar in terms of gender, aggressive behaviour, academic competence, attractiveness and popularity (Cairns et al., 1998; Xie, Cairns \& Cairns 1999). And even when there is variation and mobility of the members around different networks, there is a tendency to keep the homogeneous pattern in the new group (Cairns et al., 1998). With respect to the sociometric status, there is also a general homogeneity in the cliques, existing, for instance, larger cliques of popular children and smaller groups of rejected children. But despite this homogeneity, central members differ in terms of their salient features and sometimes different sociometric status (Bagwell et al., 2000), which depend on the clique's characteristics and norms. However, there are some general characteristics by which central member can be recognized, namely, 
precocious cross-gender behaviour (Howe, 2010), coolness, athletics and aggression for boys, and popularity, high socioeconomic status and good looks for girls (Howe, 2010; Xie, et al., 1999).

Special attention is paid to the patterns of aggression found in stratified boys cliques. In a study with 695 seventh graders, Cairns et al. (1988) found that some aggressive children were not rejected and actually enjoyed a central position in the group. The group they formed were similar in terms of levels of aggression and the leaders were recognised as controversial aggressive children, who despite being disliked by many, still had a central position in their classroom. In this study, members of these stratified boys' cliques were more likely to drop-out, or be suspended or expelled. The same pattern was encountered by Bagwell et al. (2000) in their study of 824 preadolescents, in which controversial children, especially boys, were found to be central members of deviant groups, and who were recognised by their peers as visible members of the classroom. Teachers' recognition of leaders and intervention through their figure may have an impact at the individual and classroom level, but as these children normally develop conflictual relationships with their teachers, it seems likely to be a challenging issue for teachers.

The dynamics of deviant cliques and the behaviour of aggressive children (controversial and rejected) are relevant as they affect both the academic trajectories of those children and the learning climate of the classroom. As noted, aggressive children can also develop social abilities, which determine their status and centrality. Gest, Graham-Bermann, and Hartup (2001) found that aggressive-controversial children, who are at the same time socially competent, are generally central members of deviant cliques and express their aggression by picking on others, teasing and showing off. On the other hand, aggressiverejected children, who are not sociable, have a more peripheral position in their networks and express their aggression by losing their temper and getting into fights. Even though they occupy a peripheral position, aggressive-rejected children are more likely to associate with deviant groups and are at greater risk of engaging in antisocial behaviour in order to achieve higher status within their deviant cliques (Bagwell et al., 2000). In this fashion, rejected-aggressive children act according to the values and norms of their group to become more central in their deviant clique. In these groups, rather than the social competences of cooperation and equality, characteristic of reciprocal and mutual friendships, children are exposed to relations of coercion, conflict instigation and dominance (Bagwell et al., 2000). So far, the complex reality of informal peer relationships has been highlighted, considering its importance for children's development and school performance and so providing reasons 'why' teachers should concern themselves with those relationships. In the next section we focus on 'how' teachers should concern themselves as part of the educational system as a whole.

\section{Teachers influence on peer relations}

As discussed, peer interactions affect children's development and school performance. As regards teachers, their impact on engagement and school motivation is also known (Skinner \& Bemont, 1993). When teachers relate to children in an emotionally supportive way they can promote prosocial behaviour (Luckner \& Pianta, 2011), but their rejection can reinforce disengagement (Mercer \& DeRosier, 2008). Moreover, Hughes and Kwok (2006), in a two-year longitudinal study of 360 children at academic risk, found that teacherstudent relationships in the first grade predicted peer acceptance in the second grade, and that this effect was mediated by children's classroom engagement.

Classrooms are complex contexts with particular institutionalised interaction norms. Teachers guide these norms by making clear what is expected in terms of behaviour and social interactions (Farmer et al., 2011). However, students construct their own norms, in which teachers sometimes play just a background role in terms of informal peer relations (Cairns et al., 1998). Moreover, it has been found that peer influences tend to be stronger when teachers are perceived to be less involved (Kindermann \& Vollet, 2014), but only in a very small proportion (4 per cent of the variance), which suggests that other reasons may be more relevant when it comes to explaining peer relations, and particularly their norms. The complexity of classroom interactions and the ways in which social relations and dynamics affect each other are difficult to isolate and analyse. However, they are still important for research as they affect children's development and can suggest 
ideas about how to improve teaching practice and promote a better school environment for healthier relationships.

In the remainder of this last section, I will describe three roles played by teachers, which I have identified in the literature as being relevant to their concern and practice, namely: a) teachers as protectors against the negative consequences of peer relations; b) teachers as 'architects' of classroom structure and dynamics; and c) teachers as social referents. Since these three roles are clearly interrelated, the divisions are just used for pragmatics purposes. At the end, an alternative way of showing concern which relates to Howe's ideas is included, and a fourth heading is used, namely d) teachers' and students' relationships as part of a pedagogic mode.

\section{a) Teachers as protectors against} negative consequences of peer relations

Some of the available evidence allows to hypothesise that teachers play a protective role in relation to children who have conflictual peer relations.For example, Silver, Measelle, and Armstrong (2005) with regression analysis showed that children who present high levels of aggression at the beginning of school may reduce the possibilities of externalising this kind of behaviour if they develop an early close relationship with their teachers. This is important because, as discussed, aggressive children are at greater risk of rejection, antisocial behaviour and victimisation. Regarding victimisation, a close relationship with the teacher can reduce its severity over time (Runion \& Shaw, 2013). Besides, for children who are neglected by their peers or have conflictual relations with them, teachers' relatedness can result in more academic engagement (Furrer \& Skinner, 2003) and the development of a more positive self-concept, which in turn would reduce the risk of internalising problems related to peer conflict (Spilt, van Lier, Leflot, Onghena, \& Colpin, 2014). Even though the just referenced studies evidence that teachers could play a protective role preventing negative consequences in some peer relations, there is no a clear mechanism to explain how this protective role is developed. One possible hypothesis is that teachers might help students to regulate their social behaviour and attitude to school achievement.

b) Teachers as 'architects' of classroom structure and dynamics
Some authors have developed the idea of teachers as 'architects' of classroom structures and social dynamics, implying the systematic use of strategies to promote better peer relations (Farmer et al., 2011). According to this idea, different interventions have been developed to enhance the classroom climate. A study made by Hamm, Farmer, Dadisman, Gravelle, and Murray (2011) on 14 experimental and 12 control classrooms to evaluate an intervention relating to teachers' attunement to social dynamics showed that teachers who participated in the intervention were more attuned to student social dynamics, thus they responded better to aggression, being more aware of peer status, actively monitoring students' interactions and organising groups according to student dynamics, which resulted in a better affective climate and student adjustment. Along the same lines, Gest, Madill, Zadzora, Miller, and Rodkin (2014) found in 54 classrooms that teachers who were aware of social dynamics mitigated status extremes, supported isolated children, managed aggressive behaviour and promoted prosocial behaviour, all of which impacted on student adjustment and fostered the development of a greater sense of community within the classroom. Although these interventions had a small impact, they appeared relevant to helping teacher's attunement to students' dynamics.

Special attention has been paid to on how teachers should manage aggression. It is expected that teachers should place a ban on aggressive behaviour and try to create positive climates. In this way it has been found, although to a small extent, that children benefit from classroom activities being highly organised, which enhances cooperation and gives less space for aggression (Luckner \& Pianta, 2011). The recognition of social dynamics and how to manage them is also relevant because, as concluded by McFarland (2001), when teachers fail to do so, then popular cliques can take control of the classroom dynamics, which could have important implications in the case of a very hierarchical classroom, where victimisation tends to be greater, as seen by Serdiouk, Rodkin, Madill, Logis, and Gest (2013). However, the open negative reaction of teachers towards aggressive behaviour could also be detrimental, so, in contrast, a more understanding attitude from teachers to aggressive children can translate into less rejection by peers of such children, helping in this way to break the vicious circle of aggression-rejection-aggression. 
Supporting this claim, Chang (2003) in a study with 4,650 Chinese students (13-16 years old) found that the more aversion teacher showed to aggression, the greater the rejection of the child, and on the contrary, the more understanding and tolerant a teacher was of aggression, the more levels of rejection grounded on aggression decreased. In this way, teachers contribute to developing a positive classroom climate, making clear what it is expected and permitted in the classroom, and also acting as social referents for students' relationships.

\section{c) Teachers as social referents}

Teachers can act as social referents, influencing with their behaviour - even without intending to - children's perception of their peers. Some researchers have coined the metaphor of the 'invisible hand' to talk about the influence of teachers on peer relations that, according to them, have traditionally been ignored in peer research (Farmer et al., 2011).

In this respect, it has been maintained that teacher preference predicts peer acceptance (Taylor $\&$ Trickett, 1989), or that a secure relationship with teachers promotes social competence with classmates, while dependent relationships with teacher predict social withdrawal and aggression from peers (Howes, Hamilton, \& Matheson, 1994). But even when these studies are longitudinal, it is difficult to tell precisely if it is a prediction or a correlation, as it is logical to think that children who develop positive relationships with their teacher will do the same with their peers, and students who are aggressive can have conflictual relationships both with teachers and peers. In this sense Troop-Gordon and Kopp (2011), in a study of 410 fourth and fifth graders and their 25 teachers, found that students who developed dependent relationships with their teachers had fewer friends and were more at risk of being victimised by their peers, and that both relationships could be explained more in terms of children's withdrawal than the teacher's influence. Furthermore, they did not find that teacher preference explained peer acceptance, which could be related to the children's characteristics, but also by their age as they were older in this study. It is known that the number of friends and the time children spend together increases dramatically from middle childhood to adolescence (Brown \& Dietz, 2009), so this pattern might also have reduced teachers' influence accordingly.
Experimental studies have been also conducted to analyse teachers' influence on peer relations. White and Kistner (1992) and White and Jones (2000) carried out studies with preschool, first- and second-grade children, using videos of classroom scenes to evaluate children's responses to teachers' feedback to a child with behaviour problems. The teacher's feedback could be positive, neutral, corrective, or derogatory and it was shown to have an effect, albeit small, on the children's evaluation of the problematic child. Similar findings were encountered by McAuliffe, Hubbard, and Romano (2009), in the first study using naturalistic classroom observation to analyse teachers' behaviours in relation to peer relations. In this study, conducted in 12 different classrooms, it was found, also to just a small extent, that teachers' corrective behaviour towards a child influenced children's evaluation of how much a classmate was disliked. In accordance with the literature, the principal peer rejection factor was associated with the child's aggressive behaviour, but teachers' behaviour was still shown to play a reinforcing role in relation to rejection, which is worrying considering the negative implications of peer rejection.

In the last study, as in the others, it is possible to hypothesise that the direction of the influence is not lineal or unique and probably mutual reinforcement exists in all the interactions that take place in the classroom. Along these lines, Mercer and DeRosier (2008), in a two-year longitudinal study of 1,193 third-grade students, evidenced bidirectional relations between peer rejection and teacher preference. Despite the reciprocity of the influences, the effect of peer rejection on teacher preference was shown to be greater than vice versa. In this sense, they exposed data that question and make more complex the image of the 'architectteacher'. In the same way, DeLaet et al. (2014) also added more complexity with the findings of their study of 586 fourth to sixth graders in 32 classroom in Belgium, where not only reciprocal relationships were found, but it was also observed that popular-conflictive students who had a central position in the classroom networks used conflict with teachers to increase their visibility and popularity.

There are interesting evidences from school interventions like the Head Start REDI program implemented in the United States in low-incomes 
contexts, where teachers are coached to carry out activities and instructional strategies to specifically foster socioemotional and cognitive development. In this program teachers learn how to manage their classroom, providing positive support, emotion coaching and problem-solving dialogue. Different studies by Karen Bierman have shown the positive impact of this program. For example, in a longitudinal study with 556 pree-school children (where 288 received the classroom intervention) Bierman, Heinrichs, Welsh, Nix, and Gest (2017) found that the students who were part of intervened classrooms developed in a greater extent their social competence, peer relations, social-emotional skills and also improved their grades in second year. The importance of training and guiding teachers in their relevant role as social referent for healthy peer relations is also supported by the investigation conducted by Cappella, Hamre, Kim, Henry, Frazier, Atkins and Schoenwald (2012), in which through classroom observations they found that teachers that received coaching along with training (intervention group) showed greater effects on teacher-student relationship closeness and peer victimisation than their colleagues that only received training without coaching (control conditions). The literature evidences the complexity of peer relations and teachers-student interactions. The dynamics of these relationships are immersed in the school system, which in turn also affects them. In the next section we address the pedagogic mode which frames the interactions. This enriches the discussion and provides an alternative way in which teachers and educational systems in general should show concern about informal peer relationships.

\section{d) Teachers' and students'} relationships as part of a pedagogic mode

As noted at the beginning of the text, Howe (2010) contributes to the literature on informal peer group relationships by looking at them in relation to the institutionalised pedagogical context in which they take place. Taking into account the views of Piaget and Vygotsky on children's cognitive development, she considers that peer group interactions are fundamental to learning, in spite of having been ignored by the traditional school system. By proposing the concepts of performance mode and cooperative mode, she describes how peer group relationships are experienced differently by children in each case, as the relevance and function such relationships have in each mode vary. While in the performance mode teachers interact with the class as a whole or with one student at a time (with the other students playing the role of the audience), in the cooperative mode peer interactions are promoted as central features of academic activity, whereas teacher-student interaction is less salient, although still fundamental for children's learning. Moreover, the author maintains that the two modes affect peer relations in a different manner, as they influence the levels of sociability, aggression, and withdrawal differently. On the one hand, sociability is promoted in the cooperative mode and withdrawal is reduced since interactions are needed to complete cooperative academic tasks, and on the other hand, teachers' negative feedback about aggression is reduced, which, as discussed, has repercussions for peer relations. Howe's approach thus enriches the discussion on peer relations, proposing that the same interactions that are considered as relevant to cognitive development in the cooperative mode, also provide conditions for the development of positive peer relationships.

Howe refers to a meta-analytic review of 148 studies of teenagers (12-15 years) made by Roseth, Johnson and Johnson (2008, in Howe, 2010), in which it is shown that cooperative learning -although not the same as the more general cooperative mode- positively affects peer group relationships as well as academic performance. In a more recent investigation of 217 students in 10 different elementary classrooms from the third to the fifth grade, Choi, Johnson, and Johnson (2011) identified the fact that cooperative experiences, when compared to competitive experiences, were also associated with lees aggression in the classroom. It is important to mention, though, that the data of this study was collected only through students' self-reports.

With this additional level of analysis, the ways in which teacher should show concern are understood in relation to a wider educational context in which they perform a role. In my view, this approach is interesting because it addresses children's development from a contextual and integrated perspective.

\section{Conclusion}

This essay has highlighted the importance of children's informal relationships at school, as they affect children's development and school 
performance. That may be a sufficient reason for teachers to concern themselves with those relations but, as has also been discussed, teachers, consciously or otherwise, also influence those relationships, which put teachers in an even more relevant position, compelling them to take an active and more conscious role in promoting positive and healthy relationships at school.

As has been highlighted at the end of the essay, it may be beneficial for children's relationships and learning to adopt a cooperative mode of teaching, as it fosters relations that promote sociability, reduce withdrawal, and may also reduce aggression, at the same time promoting cognitive development. Nevertheless, given that social relations are influenced for many factors, some of them outside the classroom setting it is naive to think that the conflictual relationships would disappear from one day to another just by changing the teaching system. For example, regarding aggressiveness, and the rejected and controversial sociometric status that are generally related to this behaviour, it is clear that there are other intervening factors beyond the scope of teachers, as are cultural, family and biological factors.

Along with a different mode of teaching, it is also important for teachers to concern themselves with how they can perform a protective role, or be 'architects' of classroom structures and dynamics, acting as social referents for their students' behaviour. When teachers are attuned to their student's social dynamics they may be able to help them in their school adjustment, preventing the potential development of personal and social problems. In this sense, and drawing on the reviewed empirical evidence, I think teachers should be particularly aware of their protective role and their influence in the early years, when, as studies show, they can impact positively on children's school adjustment and engagement.

Teachers should also concern themselves with how they may be part of negative reinforcing cycles. Teachers can avoid negative feedback to aggressive-rejected children so as to avoid further rejection, and they should also be aware that sometimes 'deviant leaders' can use conflict with them to reinforce their conflictual popularity in the classroom. The relationships that teachers build with aggressive children are important because of the difficulties that these children can develop in their life trajectories. There is evidence that aggressive children engage with and adapt better to school when they encounter a warm and caring teacher figure, rather than with a severe authoritarian figure that reinforces their rejection by peers.

Informal peer relations can provide rich potential context for emotional, social and cognitive development if children experience them in a positive manner. That is why teachers, along with the school system, should concern themselves with promoting children's wellbeing and healthy development. 


\section{Referencias}

Adler, P. A. \& Adler, P. (1995). Dynamics of inclusion and exclusion in preadolescent cliques. Social Psychology Quarterly, 58(3), 145-162. doi:10.2307/2787039

Bagwell, C. L., Coie, J. D., Terry, R. A., \& Lochman, J. E. (2000). Peer Clique Participation and Social Status in Preadolescence. Merrill-Palmer Quarterly, 46(2), 280-305.

Bierman, K., Heinrichs, B., Welsh, J., Nix, R., \& Gest, S. (2017). Enriching preschool classrooms and home visits with evidencebased programming: sustained benefits for low-income children. Journal of Child Psychology and Psychiatry, 58(2), 129-137.

Boaler, J., Wiliam, D., \& Brown, M. (2000). Students' experiences of ability grouping - disaffection, polarisation and the construction of failure. British Educational Research Journal, 26(5), 631-648.

Brown, B.B. \& Dietz, E.L. (2009). Informal peer groups in middle childhood and adolescence. In K. H. Rubin, W. M. Bukowski, \& B. Laursen (Eds.), Handbook of peer interactions, relationships, and groups (pp. 361-376). New York, NY, US: Guilford Press.

Buhs, E. S., Ladd, G. W., \& Herald, S. L. (2006). Peer exclusion and victimization: Processes that mediate the relation between peer group rejection and children's classroom engagement and achievement? Journal of Educational Psychology, 98(1), 1-13. doi:10.1037/0022-0663.98.1.1

Bukowski, W.M., Motzoi, C., \& Meyer, F. (2009). Friendship as process, function, and outcome. In K. H. Rubin, W. M. Bukowski, \& B. Laursen (Eds.), Handbook of peer interactions, relationships, and groups (pp. 217-231). New York, NY, US: Guilford Press.

Cairns, R. B., Cairns, B. D., Neckerman, H. J., Gest, S. D., \& Gariépy, J.-L. (1988). Social networks and aggressive behavior: Peer support or peer rejection? Developmental Psychology, 24(6), 815-823. doi:10.1037/0012-1649.24.6.815

Cairns, R. B., Xie, H., \& Leung, M.-C. (1998). The popularity of friendship and the neglect of social networks: toward a new balance. New Directions For Child Development, (80), 25-53.

Cappella, E., Hamre, B., Kim, H., Henry, D., Frazier, S., Atkins, M., \& Schoenwald, S. (2012). Teacher consultation and coaching within mental health practice: Classroom and child effects in urban elementary schools. Journal of consulting and clinical psychology, 80(4), 597-610.

Chen, X., Chang, L., \& He, Y. (2003). The peer group as a context Mediating and moderating effects on relations between academic achievement and social functioning in Chinese children. Child Development, 74(3), 710-727. doi:10.1111/1467-8624.00564

Chang, L. (2003). Variable Effects of Children's Aggression, Social Withdrawal, and Prosocial Leadership as Functions of Teacher Beliefs and Behaviors. Child Development, 74(2), 535-548.

Choi, J., Johnson, D. W., \& Johnson, R. (2011). Relationships among cooperative learning experiences, social interdependence, children's aggression, victimization, and prosocial behaviors. Journal of Applied Social Psychology, 41(4), 976-1003. doi:10.1111/j.1559-1816.2011.00744.x

Coie, J. D., \& Dodge, K. A. (1983). Continuities and changes in children's social status: A five-year longitudinal study. MerrillPalmer Quarterly, 29(3), 261-282.

Coie, J. D., Dodge, K. A., \& Coppotelli, H. (1982). Dimensions and types of social status: A cross-age perspective. Developmental Psychology, 18(4), 557-570. doi:10.1037/0012-1649.18.4.557
Cuadros, O. \& Berger, C. (2016). The protective role of friendship quality on the wellbeing of adolescents victimized by peers. Journal of youth and adolescence, 45(9), 1877-1888.

De Laet, S., Doumen, S., Vervoort, E., Colpin, H., Van Leeuwen, K., Goossens, L., \& Verschueren, K. (2014). Transactional Links Between Teacher-Child Relationship Quality and Perceived Versus Sociometric Popularity: A Three-Wave Longitudinal Study. Child Development, 85(4), 1647-1662. doi:10.1111/cdev.12216

DeRosier, M. E. \& Lloyd, S. W. (2010). The Impact of Children's Social Adjustment on Academic Outcomes. Reading \& Writing Quarterly, 27(1-2), 25-47. doi:10.1080/10573569.2011.532710

Farmer, T. W., McAuliffe, M., \& Hamm, J. V. (2011). Revealing the Invisible Hand: The Role of Teachers in Children's Peer Experiences. Journal of Applied Developmental Psychology, $32(5), 247-256$

Fredricks, J. A., Blumenfeld, P. C., \& Paris, A. H. (2004). School Engagement: Potential of the Concept, State of the Evidence. Review of Educational Research, 74(1), 59-109. doi:10.3102/00346543074001059

Furrer, C. \& Skinner, E. (2003). Sense of relatedness as a factor in children's academic engagement and performance. Journal of Educational Psychology, 95(1), 148-162. doi:10.1037/0022-0663.95.1.148

Gest, S. D., Graham-Bermann, S. A., \& Hartup, W. W. (2001). Peer Experience: Common and Unique Features of Number of Friendships, Social Network Centrality, and Sociometric Status. Social Development, 10(1), 23-40.

Gest, S. D., Madill, R. A., Zadzora, K. M., Miller, A. M., \& Rodkin, P. C. (2014). Teacher Management of Elementary Classroom Social Dynamics: Associations with Changes in Student Adjustment. Journal of Emotional and Behavioral Disorders, 22(2), 107-118.

Hamm, J. V., Farmer, T. W., Dadisman, K., Gravelle, M., \& Murray, A. R. (2011). Teachers' Attunement to Students' Peer Group Affiliations as a Source of Improved Student Experiences of the School Social-Affective Context following the Middle School Transition. Journal of Applied Developmental Psychology, 32(5), 267-277.

Hartup, W. W. (1996). Cooperation, close relationships, and cognitive development. In W. M. Bukowski, A. F. Newcomb, \& W. W. Hartup (Eds.), The company they keep: Friendship in childhood and adolescence (pp. 213-237). New York, NY, US: Cambridge University Press.

Hartup, W.W. (2009). Critical issues and theoretical viewpoints. In K. H. Rubin, W. M. Bukowski, \& B. Laursen (Eds.), Handbook of peer interactions, relationships, and groups (pp.3-19). New York, NY, US: Guilford Press.

Howe, C. (2010). Peer groups and children's development. Oxford: Wiley-Blackwell

Howes, C., Hamilton, C.E., \& Matheson, C.C. (1994). Children's Relationships with Peers: Differential Associations with Aspects of the Teacher-Child Relationship. Child Development, 65(1), 253-263.

Hughes, J. N. \& Kwok, O. (2006). Classroom engagement mediates the effect of teacher-student support on elementary students' peer acceptance: A prospective analysis. Journal of School Psychology, 43(6), 465-480. doi:10.1016/j.jsp.2005.10.001 
Kindermann, T. A. (2007). Effects of Naturally Existing Peer Groups on Changes in Academic Engagement in a Cohort of Sixth Graders. Child Development, 78(4), 1186-1203.

Kindermann, T. A. (2011). Commentary: The Invisible Hand of the Teacher. Journal of Applied Developmental Psychology, 32(5), 304-308.

Kindermann, T. A. \& Gest, S.D. (2009). Assessment of the peer group: identifying naturally occurring social networks and capturing their effects. In K. H. Rubin, W. M. Bukowski, \& B. Laursen (Eds.), Handbook of peer interactions, relationships, and groups (pp. 100-117). New York, NY, US: Guilford Press.

Kindermann, T. A. \& Vollet, J. W. (2014). Social networks within classroom ecologies: peer effects on students' engagement in the context of relationships with teachers and parents. Zeitschrift Für Erziehungswissenschaft, 17(5), 135-151. doi:10.1007/ s11618-014-0555-9

Ladd, G. W. (1990). Having friends, Keeping friends, making friends, and being liked by peers in the classroom: Predictors of children's early school adjustment? Child Development, 61(4), 1081-1100. doi:10.2307/1130877

Ladd, G. W. \& Burgess, K. B. (1999). Charting the relationship trajectories of aggressive, withdrawn, and aggressive/withdrawn children during early grade school. Child Development, 70(4), 910-929. doi:10.1111/1467-8624.00066

Ladd, G. W., Kochenderfer, B. J., \& Coleman, C. C. (1997). Classroom peer acceptance, friendship, and victimization: Distinct relational systems that contribute uniquely to children's school adjustment? Child Development, 68(6), 1181-1197. doi: $10.2307 / 1132300$

Luckner, A. E. \& Pianta, R. C. (2011). Teacher-Student Interactions in Fifth Grade Classrooms: Relations with Children's Peer Behavior. Journal of Applied Developmental Psychology, 32(5), 257-266.

McAuliffe, M. D., Hubbard, J. A., \& Romano, L. J. (2009). The Role of Teacher Cognition and Behavior in Children's Peer Relations. Journal of Abnormal Child Psychology, 37(5), 665-677. doi:10.1007/s10802-009-9305-5

McFarland, D. A. (2001). Student resistance: How the formal and informal organization of classrooms facilitate everyday forms of student defiance. American Journal of Sociology, 107(3), 612-678. doi:10.1086/338779

Mercer, S. H. \& DeRosier, M. E. (2008). Teacher Preference, Peer Rejection, and Student Aggression: A Prospective Study of Transactional Influence and Independent Contributions to Emotional Adjustment and Grades. Journal of School Psychology, 46(6), 661-685.

Newcomb, A. F. \& Bagwell, C. L. (1995). Children's friendship relations: A meta-analytic review. Psychological Bulletin, 117(2), 306-347. doi:10.1037/0033-2909.117.2.306

Newcomb, A.F. \& Bagwell, C.L. (1996). The developmental significance of children's friendship relations. In W. M. Bukowski, A. F. Newcomb, \& W. W. Hartup (Eds.), The company they keep: Friendship in childhood and adolescence (pp. 289-321). New York, NY, US: Cambridge University Press.

Newcomb, A. F., Bukowski, W. M., \& Pattee, L. (1993). Children's peer relations: A meta-analytic review of popular, rejected, neglected, controversial, and average sociometric status. Psychological Bulletin, 113(1), 99-128. doi:10.1037/0033-2909.113.1.99

Ollendick, T. H., Weist, M. D., Borden, M. C., \& Greene, R. W. (1992). Sociometric status and academic, behavioral, and psychological adjustment: A five-year longitudinal study. Journal of Consulting and Clinical Psychology, 60(1), 80-87. doi:10.1037/0022-006X.60.1.80

Parker, J. G. \& Asher, S. R. (1987). Peer relations and later personal adjustment: Are low-accepted children at risk? Psychological Bulletin, 102(3), 357-389. doi:10.1037/0033-2909.102.3.357

Parkhurst, J. T. \& Hopmeyer, A. (1998). Sociometric popularity and peer-perceived popularity: Two distinct dimensions of peer status. The Journal of Early Adolescence, 18(2), 125-144. doi:10.1177/0272431698018002001

Runions, K. C., \& Shaw, T. (2013). Teacher-child relationship, child withdrawal and aggression in the development of peer victimization. Journal of Applied Developmental Psychology, 34(6), 319-327. doi:10.1016/j.appdev.2013.09.002

Serdiouk, M., Rodkin, P., Madill, R., Logis, H., \& Gest, S. (2013). Rejection and victimization among elementary school children: The buffering role of classroom-level predictors. Journal of Abnormal Child Psychology. doi:10.1007/s10802-013-9826-9

Silver, R. B., Measelle, J. R., \& Armstrong, J. M. (2005). Trajectories of classroom externalizing behavior: Contributions of child characteristics, family characteristics, and the teacherchild relationship during the school transition. Journal of School Psychology, 43(1), 39-60. doi:10.1016/j.jsp.2004.11.003

Skinner, E. A. \& Belmont, M. J. (1993). Motivation in the classroom: Reciprocal effects of teacher behavior and student engagement across the school year. Journal of Educational Psychology,85(4), 571-581. doi:10.1037/0022-0663.85.4.571

Smith, P. K., Cowie, H., \& Blades, M. (2011). Understanding children's development (5th ed.). Oxford: Wiley-Blackwell.

Spilt, J. L., van Lier, P. A. C., Leflot, G., Onghena, P., \& Colpin, H. (2014). Children's social self-concept and internalizing problems: The influence of peers and teachers. Child Development, 85(3), 1248-1256. doi:10.1111/cdev.12181

Taylor, A. R. \& Trickett, P. K. (1989). Teacher preference and children's sociometric status in the classroom. Merrill-Palmer Quarterly, 35(3), 343-361.

Troop-Gordon, W. \& Kopp, J. (2011). Teacher-Child Relationship Quality and Children's Peer Victimization and Aggressive Behavior in Late Childhood. Social Development, 20(3), 536-561.

Vygotsky, L.S. (1981). The genesis of higher mental functions. In J.V. Wertsch (Ed.), The Concept of Activity in Soviet Psychology. Armonk, NY: Sharpe.

Vygotsky, L. S. (1978). Mind in society: the development of higher psychological processes. Cambridge, Mass; London: Harvard University Press.

Wentzel, K. R. (2009). Peers and academic functioning at school. In K. H. Rubin, W. M. Bukowski, \& B. Laursen (Eds.), Handbook of peer interactions, relationships, and groups (pp. 531-547). New York, NY, US: Guilford Press.

White, K. J., \& Jones, K. (2000). Effects of teacher feedback on the reputations and peer perceptions of children with behavior problems. Journal of Experimental Child Psychology, 76(4), 302-326. doi:10.1006/jecp.1999.2552

White, K. J. \& Kistner, J. (1992). The influence of teacher feedback on young children's peer preferences and perceptions. Developmental Psychology, 28(5), 933-940. doi:10.1037/0012-1649.28.5.933

Xie, H., Cairns, R. B., \& Cairns, B. D. (1999). Social networks and configurations in inner-city schools: Aggression, 
popularity, and implications for students with EBD. Journal of Emotional and Behavioral Disorders, 7(3), 147-155. doi: $10.1177 / 106342669900700303$
Zajac, R. J. \& Hartup, W. W. (1997). Friends as coworkers: Research review and classroom implications. The Elementary School Journal, 98(1), 3-13. doi:10.1086/461881 